\title{
"Extravagant" English Books at the Library of El Escorial and Jesuit Agency
}

\author{
Ana Sáez-Hidalgo
}

Universidad de Valladolid

\begin{abstract}
[Note: this is the accepted manuscript of chapter 7 of: "'Extravagant' English Books at the library of El Escorial and the Jesuit agency." J. E. Kelly \& Hannah J. Thomas eds., Jesuit Intellectual and Physical Exchange between England and Mainland Europe, c.1580-1789. 'The World is our House'? Leiden: Brill 2019: 155-185. ISBN 978-90-04-36265-9. DOI: https://doi.org/10.1163/9789004362666 009]
\end{abstract}

Much has been written about the relations between England and Spain in the second half of the sixteenth and the early decades of the seventeenth centuries: the political and religious confrontations and subsequent peace negotiations, and even their cultural consequences in the production of texts-both manuscripts and printed works-as well as their circulation between the two countries. Not much is known, however, about the material evidence of these relations in book collections like the Royal Library of the Monastery of El Escorial, and the English books that the Hapsburg monarchs gathered during the period. Similarly, although the Spanish crown's support of the English recusant cause is well known and has been widely studied, no trace of interaction among English Jesuits, the Inquisition, and the Spanish monarchs has been identified so far in the holdings of the library of El Escorial, the heart and emblem of the Hapsburg's ideological, religious, and political agenda. This essay analyzes a rare collection of English volumes extant in the library of the Monastery of El Escorial, ranging in variety from the core of Catholic literature and recusant propaganda to Anglican bestsellers. On the one hand, these volumes offer material evidence of the networks of English Jesuits and lay Catholics and their involvement with the book trade and the Inquisition in Spain. On the other, the collection reflects the ways in which early modern English books of varied religious confessions were gathered by Philip II (r. 1556-98) and his successors as the library of El Escorial expanded from the late sixteenth to the early seventeenth century. Despite the monarchs' inveterate defense of the Counter-Reformation and their patronage of confessional and devotional 
Catholic literature, the royal collection contains texts that were not restricted to their notion of Catholic orthodoxy. As will be seen, this collection of "extravagant" English books epitomizes a higher degree of fluidity in the early modern material and cultural exchanges between the two countries than is usually acknowledged. It demonstrates the crucial role of English Jesuits and lay Catholics as agents of this exchange and the direct and indirect effect of the ideological control of books exerted by the Inquisition.

\section{The Escorial Library: A Place for Early Modern English Books?}

In order to understand the place that English books held in the royal library of El Escorial, it is necessary to start by describing the library's intellectual foundations. Philip II was inspired to establish a library following a report from the Spanish humanist Juan Páez de Castro (c.1512-70) as early as 1556, in which Páez de Castro persuaded the king of the usefulness of gathering a book collection by describing the purpose of royal libraries in these terms:

\footnotetext{
Royal libraries are not only necessary to amend what has been published but also to supplement and make up for those pieces and whole treatises that are missing in all areas of knowledge, because neither theologians, nor doctors, nor philosophers, nor mathematicians have all the books for their disciplines. All of them are in need of the main and most ancient books. ${ }^{1}$
}

\footnotetext{
Research for this essay has been carried out with the financial support of the research project "Exilio, diplomacia y transmisión textual: Redes de intercambios entre la Península Ibérica y las Islas Británicas en la edad moderna," funded by the Agencia Española de Investigación, Ministerio de Economía y Competitividad FFI2015-66847-P. I would like to acknowledge the help of José Luis del Valle Merino and the rest of the team at the Escorial library, as well as the helpful comments of the essay's anonymous reader and the editors of the volume. I am also grateful to R.F. Yeager for his careful reading of my chapter.

${ }^{1}$ No solo son menester las librerías reales para enmendar lo publicado, pero también para suplir muchos pedazos, que les faltan, y tratados enteros en todas profesiones, porque ni teólogos, ni médicos, ni filósofos, ni matemáticos tienen todos los libros de sus facultades. A todos faltan muchos de los principales, y antiguos, que pudiera declarar fácilmente con ejemplos si no temiese la prolijidad; Juan Páez de Castro, Memoria a Felipe II sobre la utilidad de juntar una buena biblioteca: Descubierta en la Real Librería de San Lorenzo por Blas Antonio Nasarre (Valladolid: Junta de Castilla y León, 2003), 59. My translation, here and henceforward, unless otherwise stated.
} 
Castro's view on the value and usefulness of libraries was instrumental in the king's project of a royal collection, which he included in the design of his summer retreat at the Monastery of El Escorial. This ambition of completeness and service became defining features of the Escorial library, which was inspired on the one hand by Conrad Gesner's (1516-65) bibliographical compilation, the Bibliotheca universalis (Universal library), and on the other by actual contemporary libraries like that of St. Mark in Venice or the Vatican. ${ }^{2}$ With these aspirations in mind, the king involved some of the most prominent intellectuals in the project, who provided the Escorial library with a humanist—or rather a Christian humanist—design. ${ }^{3}$ The first books were donated by the king himself, but very soon the shelves were full with volumes acquired all over Europe, as well as bequeathed from individual collections-both types of donation are documented through contemporary inventories. ${ }^{4}$ From a thematic point of view, the initial aspirations of inclusiveness were fulfilled, as can be seen from the variety of books listed in the first inventories of donations and acquisitions. ${ }^{5}$

In the ensuing decades, and through the reigns of Philip Il's immediate successors, the Escorial library continued growing thanks to a combination of royal collecting and books donated or purchased from noblemen, lawyers, and book lovers. Thus, it became one of the richest libraries in Spain and Europe. With all the king's (and Páez de Castro's) aspirations for comprehensiveness, however, the library falls short in one respect: in comparison to holdings of books from other nations, sixteenth- and

\footnotetext{
2 Ibid., 113; Gregorio de Andrés, La Real Biblioteca de El Escorial (Madrid: Aldus, 1970), 9-10.

${ }^{3} \mathrm{On}$ the intellectual design of the Escorial, its connection with contemporary humanism, and its religious foundations, see Fernando Checa Cremades, "El lugar de los libros: La biblioteca del Escorial," in El libro en Palacio y otros estudios bibliográficos, ed. Pedro M. Cátedra García and M. Luisa López-Vidriero Abello (Salamanca: Universidad de Salamanca, 1996), 101-12.

${ }^{4}$ For an overview of these bequests, see De Andrés, La Real Biblioteca de El Escorial, 10-11. De Andrés has also edited the inventories of the earliest donations from Philip II $(1576,1611)$, Diego Hurtado de Mendoza (1576), Teófilo Ventura (1576), Pedro Fajardo (1581), and Alonso Ramírez de Prado (1611); Documentos para la historia de El Escorial: Vol. VII (Madrid: Imp. Sáez, 1964). This is one of the seventeen published volumes of documentary records of the history of the Monastery of San Lorenzo de El Escorial.

${ }^{5}$ On the monarch's interests for the library, see Elisa Ruiz, "La pasión anticuaria al servicio de Felipe II," in Cátedra García and López-Vidriero Abello, El libro en Palacio, 243-64, esp. 260-61. The intellectual design was soon accompanied by a powerful visual program, which can still be seen in the frescoes of the library; the earliest description and interpretation of these frescoes was undertaken by one of the first librarians of El Escorial; see José de Sigüenza, La fundación del Monasterio de El Escorial (Valencia: CMC, 2010), 2:77ff. María M. Portuondo has analyzed the intellectual agenda of the library as seen by José de Sigüenza in his description of its frescoes in "The Study of Nature, Philosophy, and the Royal Library of San Lorenzo of the Escorial," Renaissance Quarterly 63 (2010): 1106-50. See also Rosa San Segundo Manuel, Sistemas de organización del conocimiento: la organización del conocimiento en las bibliotecas españolas (Madrid: Universidad Carlos III-Boletín Oficial del Estado, 1996), chapter 5: pp. 183-96.
} 
seventeenth-century English texts are signally underrepresented in the royal collection: of the more than ten thousand sixteenth-century printed books, only twenty-nine are from English presses. Similarly, only twenty-two of the seventeenthcentury volumes were published in England. ${ }^{6}$ Of course, a large number of English authors were printed by presses in mainland Europe. These figures are nonetheless suggestive either of the scarce interest in books produced in England, or of a poor book trade with Spain, or both. ${ }^{7}$

There are some exceptions to this, particularly when looking at preReformation authors: works by Bede (672-735), Geoffrey of Monmouth (c.1095c.1155), Alcuin (c. 735-804), Richard Rolle (1305-49), Thomas Bradwardine (c. 130049), Roger Bacon (1214-92), William of Ockham (c. 1287-1347), and Robert Grosseteste (1175-1253) can be found on the shelves of the royal library. ${ }^{8}$ Likewise, some early modern texts published in Latin by English authors reached the Escorial, particularly those representing some of the central disciplines, like history, medicine, and classical languages. The library holds copies of William Camden's (1551-1623) Britannia and John Major's (1467-1550) Historia maioris Britanniae, tam Angliae quam Scotiae (History of Britain, both England and Scotland), as well as Timothy Bright's (1549-1615) Therapeutica (Therapeutics), Thomas Moffett's Nosomantica Hippocratea (Hippocratean prognostics), and Sir John Cheke's (1514-57) handbook on the pronunciation of Greek. ${ }^{9}$ Some of these early modern Latin works were suspected of, if not completely tinged with, religious heterodoxy. However, having these books on

\footnotetext{
${ }^{6}$ All the sixteenth-century books are London prints, while the seventeenth-century ones include some Oxford ones. See José Manuel Guirau Cabas and José Luis del Valle Merino, Catálogo de impresos de los siglos XVI-XVIII de la Real Biblioteca del Monasterio de San Lorenzo del Escorial (Madrid: Patrimonio Nacional, 2010-12), vols. 1-3. There are no books printed in Scotland or Ireland from this early period. 7 This situation is not unrelated to the difficulties of exporting English books in the early modern period, see P. [Paul] G. Hoftijzer, "British Books Abroad: The Continent," in The Cambridge History of the Book in England: Vol. IV; 1557-1695, ed. John Barnard and D.F. [Donald Francis] McKenzie (Cambridge: Cambridge University Press, 2002), 735-43, here 735.

${ }^{8}$ A few manuscript English texts have also been identified; see Lucy Freeman Sandler, "An Early Fourteenth-Century English Psalter in the Escorial," Journal of the Warburg and Courtauld Institutes 42 (1979): 65-80; David Fallows, "English Song Repertories of the Mid-fifteenth Century," Proceedings of the Royal Musical Association 103 (1976-77): 61-79.

${ }^{9}$ William Camden, Britannia (Frankfurt am Main: Apud Ioannem Wechelum, impensis Petri Fischeri \& haeredum Henrici Tackii, 1590), Real Biblioteca del Monasterio del Escorial [RBME] 40-V-54; John Major, Historia maioris Britanniae, tam Angliae quam Scotiae ([Paris]: Ex officina Ascensiana, 1521), RBME 32-V-27; Timothy Bright, Therapeutica, hoc est de sanitate restituenda (Frankfurt am Main: Apud Johannem Wechelium, 1589) RBME 12-V-48; Thomas Moffett, Nosomantica Hippocratea, siue Hippocratis prognostica (Frankfurt am Main: Apud heredes Andreae Wecheli, Claudium Marnium \& Ioannem Aubrium, 1588); Sir John Cheke, De pronuntiatione graecae (Basel: Per Nicol. Episcopium iuniorem, 1555), RBME 37-VI-26.
} 
the Escorial shelves was not in contradiction with Philip's policies of ideological control insisted upon by the Holy Office, given that he envisioned his library as a new Temple of Solomon in terms of its scope of power and wisdom. ${ }^{10}$ This, combined with the universalistic pretensions behind the project of the Escorial library, led the Inquisition to grant a special license allowing forbidden books in it, though they had to be placed in a separate room only accessible to the prior, the librarian, and the inquisitors. ${ }^{11}$ Thus, the Escorial oddly became a kind of reservoir for those works listed in the Index librorum prohibitorum that were excluded from circulation in Spain or expunged for wider reading by the Inquisition. Undoubtedly, the Protestant books that became part of the royal collection were the result of its ambition for completeness. Such works were nevertheless kept under surveillance. For instance, Camden's history did not go unnoticed and was reviewed by the inquisitors at least twice, ${ }^{12}$ and so was John Foxe's (c. 1516-87) Locorum communium tituli \& ordines centum quinquaginta (A hundred and fifty titles and orders of common places), on whose title page one officer of the Inquisition recognized the author of the Acts and Monuments and deleted his name.13 On other occasions, the abbreviation "A.D." (auctor damnatus [condemned author]) was enough to indicate that the author was forbidden and therefore it was not permissible to read that or any other book by that writer in particular. A curious case is that of a copy of Henry VIII's (r.1509-47) Assertio septem sacramentorum aduersus Martinum Lutherum (1521) (Assertion of the seven sacraments against Martin Luther), whose schismatic author should have been enough reason to deem it as forbidden. The officer reviewing it, however, resolved to label it as Auctor damnatus, opus permissum

\footnotetext{
10 On Solomon's Temple as an intellectual model for the Escorial, see Antonio Martínez Ripoll, "La controversia sobre la reconstrucción del Templo de Salomón entre Arias Montano y los jesuitas del Prado y Villalpando," In Fe y sabiduría: La biblioteca. IV Centenario del Monasterio de El Escorial, edited by Francisco Solano, (Madrid: Patrimonio Nacional, 1986), 53-74. Henry Kamen has contested the model of Solomon's Temple for El Escorial; see Henry Kamen, The Escorial: Art and Power in the Renaissance (New Haven: Yale University Press, 2010), chapter 3.

${ }^{11}$ Hugo Lezcano Tosca, "Lecturas espirituales prohibidas en la Real Biblioteca de El Escorial (siglo XVI)," Libros de la Corte.es 6 (2013): 76-120, here 84. On Philip II's Counter-Reformation agenda of censorship, see also Fernando Bouza, Imagen y propaganda: Capítulos de historia cultural del reinado de Felipe II (Madrid: Akal, 1998), 183ff.

12 Two manuscript annotations on the flyleaf indicate that Camden's work was inspected in the early seventeenth century (signed by Lucas de Alaejos, 1613) and the early eighteenth century (Lorenzo de Villarrubia, 1707).

${ }^{13}$ John Foxe, Locorum communium tituli \& ordines centum quinquaginta (Basel: Ex officina Ioannis Oporini, 1557) RBME 56-IV-8.
} 
(Forbidden author, allowed book), probably acknowledging the value of its content and the way it disputes Martin Luther (1483-1546). ${ }^{14}$

It is this kind of controversial, anti-Protestant literature that prevails among the Latin works by English authors at El Escorial: from early defenders of Catholicism like John Fisher (1469-1535) (a copy of whose Assertionis lutheranae confutatio [Confutation of Luther's assertion] was acquired for Philip's personal collection as early as 1546), ${ }^{15}$ to the first history of the schism by Nicholas Sander (c. 1530-81) (which would eventually be translated into Spanish), ${ }^{16}$ including other seminal works for English recusants like Edmund Campion's (1549-81) Rationes decem (Ten reasons), and other Latin texts by controversialists like Thomas Stapleton (1535-98), and Cardinals William Allen (1532-94) and Reginald Pole (1500-58). ${ }^{20}$ Significantly, there are two copies of Robert Persons's (1546-1610) Elizabethae Angliae Reginae [...] edictum cum responsione (Elizabeth Queen of England's edict, with a response), popularly known as Philopater. ${ }^{17}$ Published in 1592, the Philopater was particularly connected with the English Jesuit's agenda in Spain, as well as being part of a campaign launched by English Catholic exiles against Elizabeth I's (r.1558-1603) 1591 proclamation condemning seminary priests. ${ }^{18}$ The first text of this pan-European propaganda campaign had been an Apologia pro Rege Catholico Philipo II (Apology for the Catholic king Philip 2nd) by Stapleton. ${ }^{19}$ The reason for such an encomiastic piece

\footnotetext{
${ }_{14}$ Regis Angliae Henrici huius nominis octaui Assertio septem sacramentorum aduersus Martinum Lutherum (Lyon: Apud Guliel. Rovillium, 1561), RBME 5-V-42. The circumstance of this book corresponds to what was defined in the second rule of Bernardo de Sandoval's Index librorum prohibitorum et expurgatorum (Madrid: Apud Ludouicum Sanchez, 1612).

${ }^{15}$ John Fisher, Assertionis lutheranae confutatio iuxta verum ac originalem archetypum nunc ad vnguem diligentissime recognita (Antwerp: In aedibus Ioannis Steelsii, 1545), RBME 58-IV-11. For more details on the purchase and binding of the book, see José Luis Gonzalo Sánchez-Molero, La "Librería rica" de Felipe II: Estudio histórico y catalogación (San Lorenzo de El Escorial: R.C.U. Escorial-Mํㅡ Cristina, 1998), 419.

16 Nicholas Sander, De origine ac progressu schismatis Anglicani libri tres (Ingolstadt: Ex officina typographica Wolfgangi Ederi, 1588), RBME 43-V-55. Pedro de Ribadeneyra (1527-1611) was its Spanish translator: Historia ecclesiatica del scisma del reyno de Inglaterra (1588).

${ }^{20}$ Edmund Campion, Rationes decem quibus fretus, certamen aduersariis obtulit in causa fidei (Rome: Ex typographia Bartholomaei Banfadini \& Titi Diani, 1584), RBME 21-VI-18.

${ }^{17}$ Persons wrote the work under the pseudonym "Andream Philopatrum." Elizabethae Angliae Reginae haeresim caluinianam propugnantis, saeuissimum in catholicos sui regni edictum [...] cum responsione. The Escorial library has a copy of the first edition (Augsburg: Apud Ioannem Fabrum, 1592), RBME 15VI-22, and a later edition (Rome: Ex typographia Aloysij Zannetti, 1593). RBME 50-VI-15.

18 Paul Hughes, ed., Tudor Royal Proclamations: Vol. III (New Haven: Yale University Press, 1969), 92.

${ }^{19}$ Stapleton was professor of scripture at Louvain by the Spanish monarch's appointment; see Marvin R. O'Connell, "Stapleton, Thomas (1535-1598), Roman Catholic theologian." Oxford Dictionary of National Biography. 32018. http://www.oxforddnb.com/view/10.1093/ref:odnb/9780198614128.001.0001/odnb9780198614128-e-26307.
} 
was Philip's support of English Catholics at different levels, including endowments for the establishment of Catholic presses in mainland Europe. ${ }^{20}$ Three years earlier, King Philip had also agreed to the foundation of the first English seminary in Spain, the Royal English College of St. Alban's in Valladolid, negotiated by Persons himself. ${ }^{21}$ Such financial and religious support was embodied by a royal visit to the Valladolid college, the account of which was published, not in Latin, but in English and Spanish. ${ }^{22}$ It is no mere coincidence that this public staging of the bonds between the king and the English exiles took place in 1592, the same year in which the first edition of Persons's Philopater was published.

Apart from these two copies of the Philopater, the Escorial library has a 1588 edition of John Gibbons's (1544-89) Concertatio Ecclesiae catholicae in Anglia (Disputation of the Catholic Church in England), which includes Persons's De persecutione anglicana (1581) (The English/Anglican persecution), among other recusant texts. ${ }^{23}$ All three works-Persons's Philopater, his Persecutione anglicana, and Gibbons's Concertatio Ecclesiae catholicae-became highly popular recusant controversy texts, not only in Spain but all over Europe as well, which no doubt explains their presence at the royal library as part of the Spanish monarch's counterreformist agenda. ${ }^{24}$

The English Catholics in Spain made use of the local printing press to publicize their situation, both translating English texts and publishing in Spanish, in order to

\footnotetext{
${ }^{20}$ Fernando Bouza has studied the Spanish royal support of St. Omers' press in connection with the dissemination of Catholic books in England; see "Contrarreforma y tipografía ¿Nada más que rosarios en sus manos?," Cuadernos de historia moderna 16 (1995): 73-88.

${ }^{21}$ On the history of the Royal English College of St. Alban's, see Michael E. Williams, St Alban's College Valladolid: Four Centuries of English Catholic Presence in Spain (London: Hurst, 1986).

${ }^{22}$ A copy of the Spanish version is extant at El Escorial: Relacion de vn sacerdote ingles (Madrid: Pedro Madrigal, 1592), RBME 22-V-50. On the texts for this and subsequent celebrations of royal visits at St. Alban's College, see Berta Cano, and Ana Sáez-Hidalgo, with Glyn Redworth and Mark Hutchings, "'Comfort without offence?' The Performance and Transmission of Exile Literature at the English College, Valladolid, 1592-1600," Renaissance and Reformation 31 (2008): 31-67; the texts are edited in Berta Cano and Ana Sáez-Hidalgo, eds., The Fruits of Exile: Emblems and Pamphlets from the English College at Valladolid (Valladolid: Royal English College, 2009).

${ }^{23}$ John Gibbons, Concertatio Ecclesiae catholicae in Anglia aduersus calvinopapistas et puritanos (Trier: Henricus Bock, 1588), RBME 3-XII-53.

${ }^{24}$ Actually, this is quite a common book in collections of religious institutions, as Latin texts of controversy were part of the Counter-Reformation curriculum. Both Gibbons's Concertatio and Persons's Philopater were used in many Spanish religious houses.
} 
secure support for their cause and local funding for their colleges. ${ }^{25}$ Some of the earliest texts published in Spanish about the persecution of Catholics in England are or have been on the Escorial shelves. The inventory of the king's books in 1611 following Philip's death lists the first of these publications in Spanish, Persons's Relacion de algunos martyrios, que de nueuo han hecho los hereges en Inglaterra (1590) (Account of some martyrdoms newly carried out by heretics in England), a volume that unfortunately is no longer extant at El Escorial library. ${ }^{26}$ In an attempt to account for the royal "investment," the founder of the English mission in Spain provided the first printed account of St. Alban's College in the last pages of the book. More connected with the experience of persecution and martyrdom are two other works, Joseph Creswell's (1557-1623) account of the martyrdom of Henry Walpole (1558-95), and Persons's narrative of the flight of the Bridgettines to Portugal through France. ${ }^{27}$ The existence of these books at El Escorial library can no doubt be connected with Philip's active involvement with the English Catholic cause throughout the 1580s and 1590s, during which the Escorial holdings experienced one of its most important periods of growth.

What can be considered more of a rarity at the library of El Escorial is the existence of texts in English, a language that was not very common in early modern Spanish libraries. ${ }^{28}$ Iberian intellectuals had a preference for classical languages; and among the vernacular languages, Spanish, Italian, or French were preferred to English. In fact, there is not a single English dictionary in the Escorial library, by contrast with the large number of dictionaries for several other languages. ${ }^{29}$ English probably raised

\footnotetext{
25 Freddy Cristóbal Domínguez, “'We must fight with paper and pens': Spanish Elizabethan Polemics 1585-1598" (PhD diss., Princeton University, 2011).

26 De Andrés, Documentos para la historia de El Escorial, 7:391-401.

27 Joseph Creswell, Historia de la vida y martirio [...] Henrique Valpolo (Madrid: Pedro de Madrigal, 1596), RBME 20.vi.9. Robert Persons, Relacion que embiaron las religiosas del Monesterio de Sion de Inglaterra [...] al padre Roberto Personio, trans. Charles Tankard (Madrid: Viuda de P. Madrigal, 1594) RBME 21-V-30.

${ }^{28}$ Books in English were rare not only in El Escorial but also in other libraries, with the exception of the English colleges, the books Philip was given on marrying Mary Tudor (r. 1554-8), and the books Count Gondomar (1567-1626) acquired as an ambassador in England. Páez de Castro also mentions the purchase of books originally coming from the English dissolution of monasteries: Arantxa Domingo Malvadi, Bibliofilia humanista en tiempos de Felipe II: La biblioteca de Juan Páez de Castro (Salamanca: Universidad de Salamanca, 2011), 421. On Philip's English books, see José Luis Gonzalo Sánchez-Molero, "Philippus, rex Hispaniae \& Angliae: La biblioteca inglesa de Felipe II," Reales sitios 160 (2004): 14-31. For Gondomar's English period and his acquisition of English books, see Carmen Manso Porto, Don Diego Sarmiento de Acuña, conde de Gondomar (1567-1626): Erudito, mecenas y bibliófilo (Santiago de Compostela: Xunta de Galicia, 1996), 19-32, 611-13, 628.

29 The number of dictionaries at the RBME is highly impressive; it covers classic and ancient languages to European vernaculars like German, Catalan, Dutch, French or Italian, including a large number of more
} 
more suspicions in the eyes of inquisitors, as can be confirmed by the fact that several sixteenth- and early seventeenth-century books in English extant at El Escorial library still bear a label on their spine indicating that they are forbidden. The keepers of orthodoxy probably associated the English language with Protestant content through copies of the Booke of Common Prayer, ${ }^{30}$ a Prymer in English and Latine, ${ }^{31}$ and vernacular works by authors like Foxe, William Perkins (1558-1602), and Philippe de Mornay (1549-1623) (in the English translation by Philip Sidney [1554-86] and Arthur Golding [1536-1606]), all of whom are also identified on the title page as condemned authors. ${ }^{32}$

\section{The "Extravagant" English Books at El Escorial: Their Jesuit Provenance}

Among the English works at El Escorial library that bear on their spine the label indicating their prohibition, a few of them deserve especial attention because they can be identified as a group, even if thematically disparate. ${ }^{33}$ These books very likely went through the hands of English Jesuits. Three codicological aspects common to all of them bind them as a group. First, a shelf mark has been noted in the same hand at the bottom of the title pages of these books, suggesting that they all came from another private collection eventually incorporated in El Escorial through purchase or donation. However, these shelf marks do not match those of any of the collections known to have become part of the Escorial library. ${ }^{34}$ Second, next to these shelf marks, a different hand

exotic ones such as Quechua, Ethiopian, Armenian, Arab, and other Middle Eastern languages. See Guirau Cabas and Valle Merino, Catálogo de impresos.

${ }^{30}$ The Booke of Common Prayer (London: Christopher Barker, [1578?]), RBME 35-II-25.

${ }^{31}$ The volume at El Escorial is an incomplete copy of The Prymer in English and Latine (London: By the assygnes Ihon Wayland, forbidding all other to printe thos or any other primer, [1558]), RBME 105-VII26.

32 John Foxe, Acts and Monuments ([London]: [John Day], [1562-63]; RBME 73-VIII-7), a very worn copy; William Perkins, A Golden Chaine, or, the Description of Theologie (London: Iohn Legatte, 1612), RBME 37-II-69, also in quite bad condition. There are two copies of Philippe de Mornay, seigneur du Plessis-Marly, A Worke concerning the Trewnesse of Christian Religion (London: Robert Robinson for I.B., 1592), RBME 13-V-32, RBME 115-VII-19. All of these authors had been condemned throughout different editions of the Roman and Spanish Indices. Foxe was forbidden in the first index; Perkins in 1605, de Mornay in 1596. See Jesús Martínez de Bujanda and Marcella Richter, Index des livres interdits: Index librorum prohibitorum 1600-1966 (Montréal: Médiaspaul, 2002).

${ }^{33}$ Sixteen books have been found to belong to this collection so far. See the appendix for the complete list with bibliographical details. The list number will be used for quick reference.

${ }^{34}$ All these shelf marks start with the roman numeral III, followed by a capital P, and then numbers that range from two to twenty-six (for example, III.P.7), written in a very distinctive hand. For the paleographical analysis of this and the other hands discussed in the following paragraphs, I am deeply grateful to Professor Mauricio Herrero of the University of Valladolid. 
has written the word "extravagant," 35 which will be explored in more depth later. Third, all the books have been inscribed on the verso of their flyleaves by two different hands that render the English titles into Spanish. For instance, John Davies's (15691626) Microcosmos (1603) is presented as: Un libro llamado, Microcosmos en el quale se descriue la natura del hombre. en Ingles. el autor se llama, Juan Dauies (A book entitled Microcosmos in which the nature of man is described. In English. The author is called John Davies). Sometimes, the explanation of the title is supplemented with additional information clearly intended to present the book to someone unfamiliar not only with the language itself but also with the text. That is the case of Richard Bancroft's (15441610) A Survay of the Pretended Holy Discipline (1593), presented by the anonymous hand as: Un libro ingles llamado Suruay y es un libro escrito por hereje inglese contra los herejes q[ue] ellos llaman puritanos en Inglaterra (An English book entitled Survey, written by an English heretic against those other heretics called Puritans in England). It seems that these explanatory annotations were added retrospectively, when this discrete set of books was incorporated into a larger collection belonging to someone for whom English was an alien language. Given that the Spanish in these translations shows an important inference of Italian, they might be the hand of Scottish scholar David Colville (c.1581-1629), appointed interpreter to Philip III (r.1598-1621), but who is best known as an Arabist and for cataloging and studying the Arabic, Greek, and Hebrew manuscripts at the Escorial library between 1617 and $1626 .{ }^{36}$ Should these annotations be in Colville's hand, they would represent an exceptional example of his role as English translator, a role that probably extended to some other English books that also have the same kind of translations on the flyleaf. ${ }^{37}$

There are many unsolved questions both about the ownership of this small book collection through time and about the moment when they were acquired for the

\footnotetext{
35 Though the hand writing this term is unequivocally the same, the word has different spellings: "extravagant," "extravagante," "extravag."

${ }^{36}$ According to De Andrés, Colville never mastered Spanish, which he usually mixed with Italian: "Cartas inéditas del humanista escocés David Colville a los monjes jerónimos del Escorial," Boletín de la Real Academia de la Historia 170 (1973): 83-155, here 90. Although Colville was more of a scholar, his role as royal translator was undoubtedly of major relevance for the cultural exchange; see also Peter E. Pormann, "Colville, David (c.1581-1629)," Oxford Dictionary of National Biography. 2 Apr. 2018. http://www.oxforddnb.com/view/10.1093/ref:odnb/9780198614128.001.0001/odnb9780198614128-e-98330; and David Worthington, Scots in the Habsburg Service, 1618-1648 (Leiden: Brill, 2004), 32-33, 55-56.

37 Some of these include the abovementioned copies of Foxe's Acts and Monuments, and the Book of Common Prayer.
} 
Escorial library. Given that the latest volume in the collection was published in 1608, this should be taken as the post quem year for their incorporation. Therefore, it was after Philip II's death that these books joined the library, perhaps sometime in the 1610s or 1620s, while Colville was working with the Arab manuscripts. Without doubt, the books were already in the library by 1635 , when the high librarian, Antonio Mauricio (d. 1636), put together a Memoria de los libros prohibidos guardados en la biblioteca de El Escorial (Memorandum of forbidden books held at the Library of El Escorial) following the 1632 index by Antonio Zapata y Cisneros (1550-1635) to identify forbidden books. ${ }^{38}$ The list ends with a section of unclassified books in different languages; under the heading "English" are to be found all of the "extravagant" books in this collection-as well as some others no longer extant at the Escorial library. These books, though not acquired in Philip II's time, show on the one hand continuity in the ambition for openness and inclusiveness of the royal library through the reigns of his immediate successors, Philip III and Philip IV (r.1621-65); on the other, they are indicative of how the labeling of forbidden books was the responsibility of the royal librarians. ${ }^{43}$

The question remains, however, about the provenance of the collection. There are two indications of ownership that are of major relevance to understanding the profile and importance of this collection, which, in turn, cast light on the Jesuit role in their preservation. These are, again, two handwritten annotations explaining-or rather justifying-the fact that books suspected of heterodoxy were in the hands of English Catholics. The first one is an English note on the flyleaf of the English translation of Pedro Mexía's (1497-1551) Historia imperial y cesárea-Historie of all the Romane Emperors (1604):

This book was remitted by the Inquisition unto me to be viewed, \& I informynge the inquisitours that it contayned divers false and slanderous reportes as it

\footnotetext{
38 The Memoria was sent by the prior Juan de Madrid to the Inquisition on March 18, 1639 (sic, vere 1635) (Archivo Histórico Nacional, secc. Inquisición, leg. 4.517, no. 1). Antonio Mauricio, high librarian at this time, was appointed prior in 1636.

${ }^{43}$ De Andrés, La Real Biblioteca de El Escorial, 14-15. It is interesting to note that parallel to the growth of El Escorial, Philip IV gathered his own private library, which was the origin of the Biblioteca Nacional in the eighteenth century; in it, the king also had several books related to recusants in Spain. Fernando Bouza, El libro y el cetro: La biblioteca de Felipe IV en la Torre Alta del Alcázar de Madrid (Salamanca: Instituto de Historia del Libro y de la Lectura, 2005), 95, 280-82.
} 
may appear pag. 522. 514, and in other places, they commanded me not to restore it to the owner who is Thomas Pit merchant of Bristow but to have it in myne owne custody until they shold give other order. John Price.

John Price (c.1577-1645) was a Jesuit who spent several years in Spain in the colleges of the English mission: he was a novice at St. Gregory's College in Seville, then moved to St. Alban's in Valladolid and, after a few years in Louvain, he was named procurator of St. George's College in Madrid for a brief period, before returning to England, where he spent the last years of his life. ${ }^{39}$ Undoubtedly, his examination of Mexía's work corresponds to his earlier Spanish period in Seville. That is the city where the Bristol merchant Thomas Pitt (d. 1613) was in 1605, after joining the Spanish Company, a trading entity reestablished immediately after the Anglo-Spanish peace (1604-5). On May 31, 1605, James I (r.1603-25) issued letters patent granting the incorporation of English merchants trading in Spain and Portugal, including Pitt. ${ }^{40}$ One of the tricky issues in the treaty negotiation had been the religious aspect, including the means for the Holy Office to search and question foreigners, examining both their beliefs and possessions. Since 1576, the Consejo de la Suprema Inquisición had required that English residents should be bound by Inquisition orders as were the Spaniards; and as historian Pauline Croft has indicated, in 1604, once the war was over, this demand was shelved. ${ }^{41}$ Although after 1604 the harassment of Englishmen in Spain significantly

\footnotetext{
${ }^{39}$ Thomas M. McCoog, S.J., English and Welsh Jesuits 1555-1650: Part II, G-Z, CRS 75 (Southampton: CRS, 1995), 272. Price was the protagonist of some turmoil at the Seville College, and one of Persons's informants. See also Thomas M. McCoog, S.J., "And Touching Our Society": Fashioning Jesuit Identity in Elizabethan England (Toronto: Pontifical Institute for Mediaeval Studies, 2013), 261-81.

${ }^{40}$ The charter mentions two Thomas Pitts, father and son; Pauline Croft, ed., The Spanish Company (London: London Record Society, 1973), 95-113. It was probably the father who was involved with trade in the Canary Islands in 1600-1; see Susan Flavin and Evan T. Jones, eds., Bristol's Trade with Ireland and the Continent: The Evidence of the Exchequer Customs Accounts (Dublin: Four Courts Press, 2009), 875, 901-2. His son stayed in Seville, where he was living in 1617, according to the records; Archivo de Protocolos, Archivo Histórico Provincial de Sevilla, Leg. 3600, fols. 388 ${ }^{\mathrm{r}}-389^{\mathrm{v}}$. I am grateful to Gonzalo Velasco, Evan Jones, and Richard Stone, from the University of Bristol, for their assistance on Bristol merchants, and to Natalia Maillard for the reference to Pitt in Seville.

${ }^{41}$ Pauline Croft, "Englishmen and the Spanish Inquisition," English Historical Review 87 (1972): 24968; and "Trading with the Enemy, 1585-1604,"' Historical Journal 32 (1989): 281-302. For Spanish control of English merchants and the intervention of English Jesuits, see Albert J. Loomie, "Religion and Elizabethan Commerce with Spain," Catholic Historical Review 50 (1964): 27-51. Irish merchants had a very different relationship with the Inquisition, mostly of collaboration, as Thomas O'Connor has argued;
} 
relaxed, there remained confusion in the interpretation of that article, because it was not included in the main body of the treaty, but rather published separately. ${ }^{47}$ Searches were still carried out, particularly in cases of suspicious foreigners like Pitt, who was not only English but, according to some sources, a privateer. ${ }^{42}$ When an English book like this translation of Mexía needed to be checked for its orthodoxy, the Inquisition frequently resorted to the staff of the English Catholic seminaries, as was the case here. ${ }^{43}$ Possibly, the English Jesuit was entrusted with the inspection of other books besides Mexía's. This could account for some of the other non-Catholic books in the collection, which he could have kept in his "owne custody until they shold give other order," and that order was never given-or perhaps not before Price left Seville at some point between 1611 and 1614 .

The second indication of ownership in this book collection appears in the first volume of Joseph Hall's (1574-1656) Epistles (1608). On the verso of the page following the table of contents, a Latin annotation reads: Veniam mihi concesserunt Apostolici Inquisitores Hispalenses retinendi hunc librum ad confutandum. Jacobus Wadesvvorth (The apostolic inquisitors of Seville granted me permission to keep this book in order to confute it. James Wadsworth). Wadsworth's need to reply to Hall becomes evident in the first letter of the volume, which is addressed to him, asking:

Tell us yet by your old ingenuitie, and by those sparks of good which yet (I hope) lie covered under your cold ashes; tell us, What divided you? Your motives shall once bee scanned before an higher barre. [...] What sawe you, what heard you a-new, that might offer

\footnotetext{
see Irish Voices from the Spanish Inquisition: Migrants, Converts and Brokers in Early Modern Iberia (Basingstoke: Palgrave Macmillan, 2016).

${ }^{47}$ Werner Thomas has shown that the number of Englishmen condemned by the Inquisition dropped: between 1559 and 1604 it was 142; between 1604 and 1648, it had declined to only thirty-seven. See Werner Thomas, La represión del protestantismo en España: 1517-1648 (Leuven: Leuven University Press, 2001), 316.

${ }^{42}$ John W.D. Powell, Bristol Privateers and Ships of War (Bristol: J.W. Arrowsmith, 1930), 44. For a more recent analysis of Bristol privateers, see William Jessop, "Privateering in Elizabethan Bristol: A Case Study on John Hopkins" (MA diss., University of Bristol, 2004).

${ }^{43}$ On the collaboration of the English college in Seville with the Inquisition, and the impact of new trade regulations, see Martin Murphy, St Gregory's College, Seville, 1592-1767, CRS 73 (London: CRS, 1992), 10-12, 124-25. See also Michel Boeglin, Inquisición y Contrarreforma: El Tribunal del Santo Oficio de Sevilla (1560-1700) (Seville: Ayuntamiento, 2006).
} 
violence to a resolved mind, and make it either to alter, or suspend? ${ }^{44}$

James Wadsworth (c.1572-1623), a graduate of Emmanuel College, Cambridge, was chaplain to Sir Charles Cornwallis (d.1629) on his trip to Spain to sign the AngloSpanish peace in Valladolid in $1605 .{ }^{45}$ During his stay in Valladolid, in his son's words,

the Iesuites [...] used other illusions stronger then their Arguments, even strange apparitions of miracles [...] And so my Father [...] was conducted forthwith by the means of Father Creswell to the uniuersity of Salamanca, whereat the next day after his arrival, hee [...] was admitted with no little joy to their Church. ${ }^{46}$

Thus, Bishop John Hall (1633-1710), Wadsworth's contemporary in Emmanuel College, wrote the above-mentioned epistle inquiring about such a surprising conversion to Catholicism. This exchange between Wadsworth and Hall lasted at least until 1615, when the terms used by the Anglican bishop had clearly escalated: "What a sorry crabbe hath Master Waddesworth at last sent vs from Sivill? I pittie the impotent malice of the man; sure that hot Region and sulphurous Religion are guiltie of his

\footnotetext{
${ }^{44}$ Joseph Hall, Epistles: The First Volume, Conteining Two Decads (London: Printed by A.H. for Eleazar Edgar \& Samuel Macham, 1608), 2-3.

${ }^{45}$ Murphy, G. (2004-09-23). "Wadsworth, James (c. 1572-1623), Church of England clergyman and Roman Catholic convert." Oxford Dictionary of National Biography. 3 Apr. 2018. http://www.oxforddnb.com/view/10.1093/ref:odnb/9780198614128.001.0001/odnb-

9780198614128-e-28389. Charlotte F. Smith's biography of Wadsworth mistakenly presented him as a Jesuit, though Thomas McCoog has confirmed in private correspondence that, despite his many and strong connections with the Jesuits, he never entered the Society. Wadsworth or Wadesworth, also known as Diego Vadesfoote in Spain, published several texts: The Contrition of a Protestant Preacher, Converted to Be a Catholiqve Scholler (1615); and a Spanish translation of James I's laws against Catholics, Las leyes nueuamente hechas en el Parlamento de Inglaterra este año de M.DC.VI. contra los catolicos ingleses, que llaman recusantes, traduzidas de su original impresso en ingles, 1606. He is frequently mistaken for his brother Paul, or Seth, Wadsworth, who was consul in Andalusia; Albert J. Loomie, "Thomas James: The English Consul of Andalucia 1556-c.1613," Recusant History 11 (1972): 165-78, here 172-74.

${ }^{46}$ Wadsworth's son, also called James (1604-56), was brought over to Spain in 1610, educated as a Catholic, and sent to St. Omers. Eventually, he escaped to England and wrote the anti-Spanish pamphlet The English Spanish Pilgrime; Or, a Neuu Discoverie of Spanish Popery, and Iesuiticall Stratagems (London, 1629), 2-3.
} 
choler. For ought I see hee is not onely turned Papist but Spaniard too." 47 Indeed, the accusation of Hispaniolization was one of the most common used against those who left England for Spain for motives of religion, in particular the Jesuits involved in the English mission, some of whom had been instrumental in Wadsworth's conversion. ${ }^{48}$ In Wadsworth's case, however, there might have been more grounds for such a charge, because he remained in Spain and became an integral part of the system, first working for the Inquisition in Seville and eventually as English tutor to the Infanta Maria Ana (1606-46) during the negotiations for the proposed Spanish Match. ${ }^{49}$ It must have been during his time in Seville that Hall's book reached Wadsworth's hands, prompting the heated exchange between them.

No documentary evidence has been found that can throw light on the question of whether the volumes in this collection of "extravagant" books came mostly from Price's or from Wadsworth's shelves. What is clear is that the collection originated in Seville, and that its gathering was the result of Inquisition searches carried out by both the English Jesuit (Price) and the English convert (Wadsworth), who worked for the Holy Office in the 1610s. Following their inspections of books suspected of heterodoxy, brought over by English merchants stopping at the city, Price and Wadsworth each retained some of them. But the collection does not only include books subject to Inquisitorial control; some of the volumes in the collection might also have belonged to the two English Catholics' personal collections, as will be explained in the next section.

\section{The Making of "Extravagant" Books}

The collection of forbidden books includes a variety of works, from Raphael Holinshed's (1529-80) Chronicles (1577), to a volume on arithmetic, Robert Recorde's

\footnotetext{
47 James Wadsworth [Sr.], The Copies of Certaine Letters Vvhich Haue Passed betweene Spaine and England in Matter of Religion (London: Printed by William Stansby for William Barret and Robert Milbourne, 1624), 30-31. This correspondence was published by William Bedell (1571-1642) after Wadsworth's death.

48 Robert Persons was frequently the target of these accusations; see Christopher Highley, Catholics Writing the Nation in Early Modern Britain (Oxford: Oxford University Press, 2008), 151-87.

${ }^{49}$ Not much is known about Wadsworth's role as English tutor of the Infanta, although there is speculation that the English translation of Cesar Oudin's A Grammar Spanish and English (1622), which includes a bilingual version of Juan de Luna's Diálogos familiares, might have been prepared by him for this purpose. On the Spanish Match, see Alexander Samson, ed., The Spanish Match: Prince Charles's Journey to Madrid, 1623 (Aldershot: Ashgate, 2006), esp. 95; Glyn Redworth, The Prince and the Infanta: The Cultural Politics of the Spanish Match (New Haven: Yale University Press, 2003).
} 
(c.1512-58) The Whetstone of Witte (1557), and a miscellany of military, didactic, and poetic texts by Thomas Churchyard (c. 1520-1604), namely General Reharsall of Warres (1579). Some of these authors had been condemned, like Recorde, whose Opera omnia was included in the 1596 Roman Index, and would later be added by Bernardo de Sandoval (1546-1618) to the Spanish 1612 Index. ${ }^{50}$ The Spanish Index librorum prohibitorum had also found lapses of orthodoxy in the biography of Constantine the Great included by Mexía in his Historial imperial y cesárea, which required some censorship. ${ }^{51}$ Those are the "divers false and slanderous reportes as it may appear pag. 522. 514" that Price expunged in the English Historie of all the Romane Emperors following the rule that established that the prohibition of a work in its original language extended to its translations. ${ }^{52}$

Not all the volumes in this collection had been listed in the Inquisition manuals for censorship, however. The reason for this was probably because works by Protestant authors, though suspicious, could be authorized as long as they did not discuss religious issues. Nevertheless, verification by the Inquisition officers was still required. ${ }^{53}$ Churchyard's text could have fallen into this category, as well as the poem by John Davies of Hereford, Microcosmos (1603). A philosophical piece dedicated to James I, it perhaps inspired inspection and approval, despite the fact that Davies came from a Catholic family. 54

The collection also includes some classic Anglican texts that could have called for a more strict intervention from the inquisitors, like John Norden's (c. 1547-1625) immensely popular A Pensive Mans Practise (1597), which went through more than forty editions within four decades; the exegetical text by Richard Turnbull (d. 1593), An Exposition upon the Canonicall Epistle of Saint Iames (1591); as well as Richard

\footnotetext{
${ }^{50}$ Jesús Martínez de Bujanda, El índice de libros prohibidos y expurgados por la Inquisición española (1551-1819) (Madrid: Biblioteca de Autores Cristianos, 2016), 931. See also Martínez de Bujanda et al., Thesaurus de la littérature interdite au XVIe siècle: Auteurs, ouvrages, éditions avec addenda et corrigenda (Paris: Librairie Droz, 1996).

${ }^{51}$ Martínez de Bujanda, El índice de libros prohibidos, 786. The Inquisition had also forbidden Mexía's account of Pope Joan in his Silva de varia lección (1540).

52 The instruction on translations comes from rule 13 of the 1612 Index (Sandoval, Index librorum, 7).

53 José Pardo-Tomás, "Censura inquisitorial y lectura de libros científicos: Una propuesta de replanteamiento," Tiempos modernos 4, no. 9 (2003): 1-18, here 5.

54 H.E.G. [Henry Edward George] Rope, "John Davies of Hereford, Catholic and Rhymer," Anglo-Welsh Review 28 (1961): 20-36. For a clarification on the two contemporary authors named John Davies, see appendix E to Mary Hampson Patterson, Domesticating the Reformation: Protestant Best Sellers, Private Devotion, and the Revolution of English Piety (Madison: Fairleigh Dickinson University Press, 2007), 327.
} 
Bancroft's anti-Puritan A Survay of the Pretended Holy Discipline (1593), the heretical character of which is acknowledged on the flyleaf of the copy at El Escorial, as noted above: "By an English heretic against those other heretics called Puritans." 55 This last book deserves special attention, as coincidentally a copy of this same title was sent to Seville for Persons by Richard Verstegan (c. 1550 - 1640) in 1593, as is recorded in a manuscript "List of the Books Sent until Seville and Packed Up in a Chest Marked Thus: Pc, for Father Persons, Rated with Their Prices."56 Beyond his interest in the condemnation of Puritans-given that the shipping included several books with similar content-Persons could have also intended to use it for exercises in controversy, for which he and the English colleges in Spain had received special permission from the Holy Office ${ }^{57}$ Although there is no sign in the copy at El Escorial indicating that this book might have been intended for Persons or for some licensed usage in one of the English institutions, what is certain is that neither Bancroft's work nor any of the other classic Anglican texts in this collection bear any trace of censorship despite the clear heretical character of their authors and most of their content. Not even the visus that used to be handwritten by way of official certification of the inspection of the volume is present, perhaps because they were not listed in the Index. ${ }^{58}$

The only annotation that is common to all the books that might imply some kind of censure is the term "extravagant(e)," which was not habitual in Holy Office inspections. Although this word appears in complete isolation and is decontextualized, and therefore its exact meaning is difficult to pin down, it is necessary to explore how it was used during this period in order to get an understanding of the reason why these works were considered as such. Originally, the medieval Latin term "extravagans" designated "stray" decrees or constitutions that were not codified or collected in Gratian or the Decretals, but very soon it went through a semantic expansion and started to be applied to non-ecclesiastical purposes, thus passing to signify "itinerant,

\footnotetext{
55 On Bancroft's anti-Puritanism, see Patrick Collinson, Richard Bancroft and Elizabethan AntiPuritanism (Cambridge: Cambridge University Press, 2013).

56 Stonyhurst College, MS Coll. B.137 and Anthony G. Petti, ed., The Letters and Despatches of Richard Verstegan, c.1550-1640, CRS 52 (London: CRS, 1959), 187-89. Earle Havens is studying this manuscript and has generously allowed me to see his notes.

57 St. Alban's College in Valladolid, for instance, was granted permission to "read all kinds of English controversies"; Archive of St. Alban's College, Series 2, book 2, no. 39; September 3, 1611.

58 On the methods used by the Inquisition with books, see Virgilio Pinto Crespo, Inquisición y control ideológico en la España del siglo XVI (Madrid: Taurus, 1983).
} 
stray, supplementary" as well. ${ }^{59}$ By the sixteenth century, the two senses were in regular use in vernacular languages, including Spanish and English. In 1599, John Minshew (1560-1627) translated the Spanish "extravagante" as "such as follow not common order," which shows that its non-specialized usage denoted some kind of deviance. ${ }^{66}$ According to the Oxford English Dictionary, at the turn of the century the meanings "straying," "divergent, discrepant," were already recorded. ${ }^{60}$ The books in this collection, not being church decrees or constitutions, must have fallen into the category of texts that do not adjust to "common order."

From what kind of order were these books deviating? Religious orthodoxy is the first to come to mind, considering the number of Anglican authors, as well as a few forbidden titles or books with passages to be censored. However, some other titles in the collection, also marked "extravagant," have an unquestionable Catholic profile. These are an edition of Persons's Christian Directory (1598), one of his most popular works (also known as The Book of Resolution), and A Briefe Apologie, or Defence of the Catholike Ecclesiastical Hierarchie (1601), as well as the Appendix to the Apology (1601).61 These two texts more specifically related to an English Catholic context, in particular to the Archpriest Controversy developing at the turn of the century. ${ }^{62} \mathrm{~A}$ fourth title connects this body of the collection with the recusant presses in mainland Europe-the Douay edition of The Miroure of the Blessed Life of Our Lorde and Savioure Iesus Christe (c.1606), Nicholas Love's translation of the Meditationes vitae Christi, traditionally attributed to St. Bonaventure, and one of the most popular devotional texts since the late Middle Ages. These four works, then, could have been in Wadsworth's or Price's hands. But it is improbable that this group of texts would be considered as "straying" from a religious perspective.

\footnotetext{
59 Dictionary of Medieval Latin from British Sources, s.v. through Logeion; http://logeion.uchicago.edu (accessed March 19, 2018).

${ }^{66}$ In 1599, Minshew published an expanded version of Richard Perceval's (1550-1620) first dictionary of Spanish and English, A Dictionarie in Spanish and English [...] Enlarged and Amplified [...] by Iohn Minsheu (London: Edm. Bollifant, 1599). For the ecclesiastical usage, he gives a different spelling, "estravagante." According to the Nuevo tesoro lexicográfico del español, Minshew's is the first recorded definition of the Spanish term; Lidio Nieto Jiménez, and Manuel Alvar Ezquerra, eds., Nuevo tesoro lexicográfico del español (s. XIV-1726) (Madrid: Arco-Libros, 2007).

60 "1. That wanders out of bounds; straying, roaming, vagrant (1602); 4. Widely divergent or discrepant (from, to); remote from, irrelevant or foreign to a purpose or subject. Obs. (1601)"; OED (2nd ed., Oxford: Oxford University Press, 2009).

${ }^{61}$ These two are bound in a single volume.

${ }^{62}$ This work was Persons's attempt to defend the authority of Rome as well as his own reputation; see Michael L. Carrafiello, Robert Parsons and English Catholicism, 1580-1610 (Selinsgrove: Susquehanna University Press, 1998), 88.
} 
The last English volume in this brief collection is entitled Second Part of the Booke of Christian Exercise, Appertayning to Resolution or a Christian Directory, Guiding All Men unto Theyr Salvation (1592). Such a title implies-falsely-that it is a new section, or a continuation of Persons's First Booke of the Christian Exercise (1582). But the English Jesuit had already published that second part, renaming it A Christian Directorie Guiding Men to Their Salvation (1585). In fact, the text at El Escorial, the Second Part of the Booke of Christian Exercise, is an anonymous Protestant adaptation of Persons's Christian Directorie, similar in fashion to what Edmund Bunny (15401619) had done in 1584 with the first version of Persons's text. The "Dedication to the Christian Reader" in the 1592 Second Part of the Booke of Christian Exercise proclaims Bunny as the model followed in "framing" Persons's Christian Directory. As with Bunny's Protestant rewriting, this anonymous 1592 version of Persons's text was extremely popular in England, with some twelve editions produced in forty years. Hence, this volume of the collection is doubtlessly "deviant" or "extravagant" from the point of view of orthodoxy. ${ }^{63}$

Notably, the Escorial copy of this anonymous Protestant Christian Directory contains profuse marginal annotation, written in two contemporary hands. Even though the annotations initially appear to be intended to correct typographical or grammatical mistakes, or smaller stylistic aspects, in actuality these anonymous hands are comparing the Protestant adaptation of Persons's text with the original edition and correcting it in order to purge the heterodox distortions. ${ }^{64}$ Thus, the purpose of these emendations seems to be to restore the "corrupt" text back to what Persons had first written rather than to contest the work for controversial purposes, as Persons had done with Bunny and was a common practice when refuting Protestant texts. ${ }^{65}$ The

\footnotetext{
${ }^{63}$ Bunny's Protestant version has received more critical attention than the Second Part, mainly because Persons contested many of the alterations of the text in the Christian Directory; Brad Gregory, "The "True and Zealous Service of God': Robert Persons, Edmund Bunny and the First Booke of the Christian Exercise," Journal of Ecclesiastical History 45 (1994): 238-68; Victor Houliston, "Why Robert Persons Would Not Be Pacified: Edmund Bunny's Theft of The Book of Resolution," in The Reckoned Expense: Edmund Campion and the Early English Jesuits, ed. Thomas M. McCoog, S.J. (Rochester, NY: Boydell Press, 1996), 159-78.

${ }^{64}$ By contrast with Bunny, where lexical emendations are not the main type of change, the alterations of the Second Part are, besides some expansion of the text, largely individual words, like "seemeth" for "seemed" (64), "people" for "nation" (126).

${ }^{65}$ For more on recusant manuscript annotations contesting Protestant texts, see Alexandra Walsham, "The Spider and the Bee: The Perils of Printing for Refutation in Early Tudor England," in Tudor Books and Readers: Materiality and the Construction of Meaning, ed. John N. King (Cambridge: Cambridge University Press, 2010), 163-90, esp. 166-73. Exile English colleges trained their students in this kind of controversy, for which Protestant books were imported, as seen above.
} 
zeal of these correctors is so meticulous that some misprints of the 1585 edition, which had been corrected in the 1592 Protestant version-misprints devoid of any religious consequence-are restored to their original form, seemingly for no other reason than to restore the 1585 edition. ${ }^{66}$ These emendations must have come from the hand of someone concerned with preserving the textual integrity of a work that was not only the bedrock of Persons's thinking but also, as the Jesuit John Gerard (1564 -1637) put it, that "has converted more souls to God than it contains pages." 67 The restoration was undoubtedly made by an English Catholic, quite probably attached to one of the English Jesuit colleges founded by Persons and whose libraries had copies of the original, orthodox edition to consult. ${ }^{68}$ St. Gregory's College in Seville seems the most likely location, a city to which several other volumes of this collection have been traced. ${ }^{69}$

Among all the books in the collection, this copy of the anonymous Protestant version of Persons's Christian Directory is exceptional in its apparatus of textual emendations. Apart from Price's identification of the passages forbidden by the Index in the English translation of Mexía, and a suppressed paragraph in the Apology, ${ }^{70}$ none of the other English books, nor the two non-English works, have any evidence of intervention denoting condemnation or censorship of the texts or authors. ${ }^{71}$ Even the flyleaf annotation for the Apology deems it a good book (Parece buen libro). Still, each of these books has been labeled as "extravagant," no matter whether it is poetry or prose; whether Anglican or Catholic; whether about religion, geography, or philosophy;

\footnotetext{
${ }^{66}$ For instance, on p. 178 the name "Baltasar" is reversed to "Balsasar," a clear mistake that was printed in the first edition.

${ }^{67}$ Quoted in Victor Houliston, Catholic Resistance in Elizabethan England (Aldershot: Ashgate, 2007), 37.

${ }^{68}$ Verstegan sent to Seville eight copies of the Directory, as well a copy Bunny's version of it. See n. xxx.

${ }^{69}$ The role of the libraries of all the English colleges in Spain was crucial not only for the English mission but also to the reception and dissemination of English recusant culture in Spain. For the specific case of St. Alban's library, see Ana Sáez-Hidalgo, "St. Alban's English College, Valladolid: Enclave or Doorway to the Reception of English Books in Spain?," South Atlantic Review 79 (2014): 105-23.

${ }^{70}$ The anonymous hand indicates that the second paragraph on p. 201 needs to be omitted because "something is therein mistaken; through the mistaken date of one of M. Benstedes letters, whereby a former letter of his was taken for a later. His first apprehension was verely thought to procede of treacherrie, upon some free speeches of his which hapned at Lincolne seemeth to have bin by a meere chance; after his breach from VVisbich, and some after he was put to death."

71 See appendix, nos. 15, 16. Curiously, one of the non-English books, the Dutch T'ghulden ghebedeboecxken, was misidentified in the flyleaf, taking it for Otto Brunfels's Dat ghulden Ghebedeboecxken uut den ouden ende nieuwen Testamente, forbidden in Gaspar de Quiroga's Index et catalogus Librorum prohibitorum (Madrid: Apud Alphonsum Gomezium Regium Typographum, 1583), 86. This caused the translator to wrongly render the title as "Un libro tedesco que contiene la Estoria del Evangelio" [A Dutch book containing the story of the Gospels]. See Martínez de Bujanda, Index des livres interdits, no. 141 (193).
} 
whether listed in the official indexes librorum prohibitorum of forbidden books or not. The only aspect common to all of them is their language: English. It is perhaps there that their "extravagant" character lies, or in the peculiarity of such a collection of disparate books resulting from the collaboration of an English Jesuit and an English convert with the Spanish Inquisition.

The uniqueness of this small collection of "extravagant" books is revealing. Not only does it embody the spirit of inclusiveness that Páez de Castro sought to inspire at the foundation of the Escorial library-a spirit contrasting in many ways with the confessionalism associated with the Hapsburgs—but it also reflects the fluidity with which books moved between Spain and England, and with which personal collections were gathered, though a fluidity that was clearly hindered by linguistic barriers. This collection of "extravagant" books is inclusive in its diversity of topics and its varying degree of orthodoxy, the result doubtlessly of multiple ownership, from the merchant Pitt to the English convert Wadsworth, including the Jesuit Price and probably some other members of St. Gregory's College in Seville. Their agency was crucial at the Spanish seaport, both in the importation of English books and in their assistance to the Inquisition with a language usually unknown to its officers. Unlike other books incorporated into the royal library, however, no discrimination was made between orthodox and unorthodox books in this collection: all of them were "extravagant," and yet bear the label indicating that they were forbidden. This must also account for how these books passed from hand to hand until they were categorized. If English Catholics like Wadsworth needed the Inquisition's permission to keep Hall's Epistles; if the Jesuit Price was asked by the Holy Office to retain the English Mexía; if the Protestant version of Persons's Christian Directory was so very meticulously reverted to its original form, then at those initial moments the heterodox nature of these texts was understood, and they were recognized as non-Catholic works. However, clearly thereafter, at some time before these volumes were gathered as the collection we know now in El Escorial, one of their several owners was unable to understand their content. On noticing both some traces of censorship and their "heretical" English language, he took those for signs to consider all of them, the truly heretical and the innocuous, "out of common order," as "extravagant." 


\title{
Appendix: Inventory of “Extravagant" Early English Vernacular Books in the Escorial Library
}

1. [Anon.]. The Second Part of the Booke of Christian Exercise, Appertayning to Resolution or a Christian Directory, Guiding All Men vnto Theyr Saluation / Vvritten by the Former Author R.P. London: Iohn Charlewood for Simon Waterson, 1592.

\author{
RBME 111-VIII-33 $\quad$ Earlier shelf mark: III-P.25 \\ Verso of flyleaf: "la $2^{\underline{a}}$ parte de un libro inglés llamado la Resolution o cristiano \\ directorio que guia los hombres a su saluacion."
}

STC 19382 / ESTC S126315 / USTC 517257

2. Bancroft, Richard. A Survay of the Pretended Holy Discipline: Containing the Beginninges, Successe, Parts, Proceedings, Authority and Doctrine of It [...]. London: Iohn Wolfe, 1593.

RBME 104-VI-27 Earlier shelf mark: III.P.9

Verso of flyleaf: "Un libro ingles llamado Suruay y es un libro escrito por hereje inglese contra los herejes q[ue] ellos llaman puritanos en Inglaterra." STC 1352 / ESTC S100667 / USTC 512303

3. [St. Bonaventure [attr.]The Miroure of the Blessed Life of Our Lorde and Savioure Iesus Christe / Written in Latin by [...] Saint Bonauenture [...]. [Douai]: [C. Boscard], [c.1606].

RBME 110-V-49 Earlier shelf mark: III.P.21.

Verso of flyleaf: "Espejo de la vida bienaventurada de nuestro señor de S. Bonaventura. Traducido en Ingles."

A\&R 128 /STC 3268 / ESTC S114205

4. Churchyard, Thomas. A General Reharsall of Warres, Called Churchyardes Choise [...]. London: Edward White, 1579.

RBME 110-V-29 Earlier shelf mark: III.P.13

Verso of flyleaf: "Una obra en inglés de soldados por Thomas Churchyard." STC 5235 / ESTC S104933 / USTC 508732 
5. Davies, John. Microcosmos: The Discovery of the Little World with the Government Thereof [...]. Oxford: Ioseph Barnes, 1603.

RBME 43-II-36

Earlier shelf mark: III.P.14.

Verso of flyleaf: "Un libro llamado, Microcosmos en el quale se descriue la natura del hombre. en Ingles. el autor se llama, Juan Davies."

STC 6333 / ESTC S109344

6. Hall, Joseph. Epistles: The First Volume, Conteining Two Decads. London: Printed by A.H. for Eleazar Edgar \& Samuel Macham, 1608.

RBME 105-VII-21 Earlier shelf mark: III.P.17

Verso of flyleaf: "Epistolas de Joseph Hall en ingles."

STC 12662 / ESTC S122077

7. Holinshed, Raphael. The Firste Volume of the Chronicles Of England, Scotlande, and Irelande. London: Imprinted for Iohn Harrison, 1577.

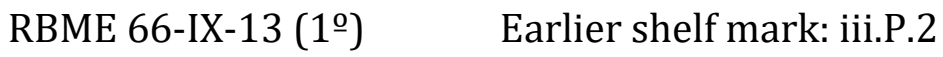

Verso of flyleaf: "Una descripcione de Inglaterra, Irlanda y escocia. / El autor V.H. quiere dezir Guglielmus Hollinshed, etc."

STC 13568 / ESTC S119439 / USTC 508385

8. Mexía, Pedro. The Historie of all the Romane Emperors [...] First Collected in Spanish by Pedro Mexia, since Enlarged in Italian by Lodouico Dulce and Girolamo Bardi, and now Englished By W.T. London: Printed for Matthevv Lownes, 1604.

RBME 58-VIII-10 Earlier shelf mark: III.P.7

Verso of flyleaf: "esta relatione escrita en ingles es buena y con buena razon esta prohibido el libro porque habla mal de algunos Pontifices, loc. cit./ Historia de los Imperadores Romanos desde Giulio Cesare hasta a Rodulfo. En Ingles.” STC 17851/ ESTC S114704

9. Norden, John. A Pensive Mans Practise, Verie Profitable for All Persons [...]. London: Robinson, 1597.

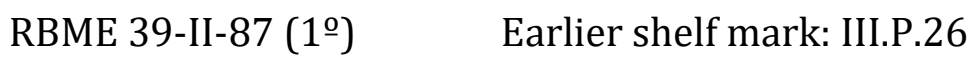

Verso of flyleaf: "la practica del hombre pensativo , por J. Norden en Ingles." 
STC 18617.6C / ESTC S96136 / USTC 517462

Note: The volume includes two other works by Norden:

- The Pensive Mans Practise: The Second Part; Or the Pensive Mans Complaint and Comfort. London J.W[indet] f. J. Oxenbridge, 1597. STC 18626a.1C/ ESTC S96138

- A Progresse of Pietie, Being the Third Part of the Pensiue Mans Practise. London: Printed by V.S[immes]. for Io. Oxenbridge, 1598. STC 18626a.3 / ESTC S94489

10. [Persons, Robert ]. A Briefe Apologie, or Defence of the Catholike Ecclesiastical Hierarchie, \& Subordination in England [...]. [Antwerp]: [Arnout Conincx], [1601].

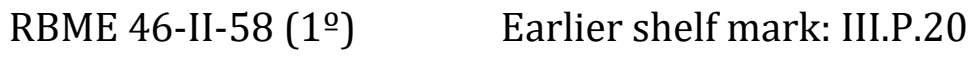

Verso of flyleaf: "Apologia de la hierarchia catholica ecclesiastica de Inglaterra en inglese sin autor. Parece buen libro."

A\&R 613 / STC 19391.5 / ESTC S105130

11. [Persons, Robert]. An Appendix to the Apologie, Lately Set Forth, for Defence of the Hierarchie, and Subordination of the English Catholike Church [...]. [Antwerp]: [Arnout Conincx], [1602].

RBME 46-II-58 (2ํㅜ)

NB: bound with no. 10

A\&R 612/ STC 19392.5 / ESTC S114168

12. [Persons, Robert], A Christian Directorie Guiding Men to their Salvation Devided into three Boores [sic] [...] And Set Forth Novv Again Vvith Many Corrections and Additions by the Athour [sic] Him Self vvith Reprofe of the Corrupt and Falsified Edition of the Same Booke Lately Published by M. Edm. Buny [...]. Louan: Laurence Kellam, 1598.

RBME 43-II-48 Earlier shelf mark: III.P.21

Verso of flyleaf: "Directorio cristiano en que se reforma el de Edmundo buny. A.

D. en ingles."

A\&R 622 / STC 19354.3 / ESTC S121960 / USTC 402440

13. Recorde, Robert. The Whetstone of Witte: Whiche Is the Seconde Parte of Arithmetike [...]. London: Ihon Kyngstone, 1557. 
RBME Mesa 18-II-22 Earlier shelf mark: iii.P.7

Verso of flyleaf: "la pietra de afilare el intendimento. un libro de la arithmetica algebraica. Ingles."

STC 20820 / ESTC S110599 / USTC 505457

14. Turnbull, Richard. An Exposition upon the Canonicall Epistle of Saint Iames. London: Iohn Windet, 1591.

RBME 104-VIII-52 Earlier shelf mark: III.P.19

Verso of flyleaf: "Comentarios de Ricardo Turnebulo sobre la epistola de S. Jago en englese."

STC 24339 / ESTC S118931 / USTC 511994

\section{"Extravagant" Early Modern Books in Languages Other Than English}

15. [Anon.] T'ghulden ghebedeboecxken met allen zijn figueren des levens Jhesu. Antwerp: Jan II van Ghelen, 1560.

RBME 113-II-13 Earlier shelf mark: III-P-26

Verso of flyleaf: "Un libro tedesco que contiene la Estoria del Evangelio."

Note: no 1560 edition has been found in USTC or in STCV (Bibliografie van het handgedrukte boekthe); only a 1576 edition [USTC 411737]. ${ }^{72}$

16. Lippomano, Luigi. Confirmatione et stabilimento di tutti i dogmi catholici con la subuersione di tutti i fondamenti, motiui \& ragioni de i moderni eretici fino al numero 482 [...]. Venice: Per Domenico Giglio, [1553].

RBME 105-VII-16

Verso of flyleaf: "Confirmatione de los dogmas catholicos contra los herejias modernas en Italiano sin autor; solamemente tiene una epistola en el principio de Luigi Lipomano obispo de Verona." "Tampoco tiene el año en que se imprimio y en medio le faltan casi cincuenta ojas en dos partes."

USTC 838222.

\footnotetext{
${ }^{72}$ I am grateful to Liesbeth Corens for assistance in the identification of this book.
} 


\section{Bibliography}

Andrés, Gregorio de. “Cartas inéditas del humanista escocés David Colville a los monjes jerónimos del Escorial." Boletín de la Real Academia de la Historia 170 (1973): 83155.

——_. Documentos para la historia de El Escorial, 17 vols. Madrid: Imp. Sáez, 1964.

_——. La Real Biblioteca de El Escorial. Madrid: Aldus, 1970.

Archivo Histórico Nacional.

Archivo Histórico Provincial de Sevilla.

Boeglin, Michel. Inquisición y Contrarreforma: El Tribunal del Santo Oficio de Sevilla (1560-1700). Seville: Ayuntamiento; ICAS; Ediciones Espuela de Plata, 2006.

Bouza, Fernando. "Contrarreforma y tipografía ¿Nada más que rosarios en sus manos?" Cuadernos de historia moderna 16 (1995): 73-88.

- - - Imagen y propaganda: Capítulos de historia cultural del reinado de Felipe II. Madrid: Akal, 1998.

- - El libro y el cetro: La biblioteca de Felipe IV en la Torre Alta del Alcázar de Madrid. Salamanca: Instituto de Historia del Libro y de la Lectura, 2005.

Bright, Timothy. Therapeutica, hoc est De sanitate restituenda. Frankfurt am Main: Apud Johannem Wechelium, 1589.

Camden, William. Britannia. Frankfurt am Main: Apud Ioannem Wechelum, impensis Petri Fischeri \& haeredum Henrici Tackii, 1590.

Campion, Edmund. Rationes decem quibus fretus, certamen aduersariis obtulit in causa fidei. Rome: ex typographia Bartholomaei Banfadini \& Titi Diani, 1584.

Cano Echevarría, Berta, and Ana Sáez-Hidalgo, with Glyn Redworth and Mark Hutchings. "'Comfort without offence?' The Performance and Transmission of Exile Literature at the English College, Valladolid, 1592-1600." Renaissance and Reformation 31 (2008): 31-67.

- - - eds. The Fruits of Exile: Emblems and Pamphlets from the English College at Valladolid. Valladolid and London: Royal English College and Maggs Bros., 2009.

Carrafiello, Michael L. Robert Parsons and English Catholicism, 1580-1610. Selinsgrove, PA: Susquehanna University Press, 1998. 
Cheke, Sir John. De pronuntiatione graecae. Basel: Per Nicol. Episcopium iuniorem, 1555.

Collinson, Patrick. Richard Bancroft and Elizabethan Anti-Puritanism. Cambridge: Cambridge University Press, 2013.

Checa Cremades, Fernando. "El lugar de los libros: la biblioteca del Escorial." In El libro en Palacio y otros estudios bibliográficos, edited by Pedro M. Cátedra García and M. Luisa López-Vidriero Abello, 101-12. Salamanca: Universidad de Salamanca, 1996.

Creswell, Joseph. Historia de la vida y martirio [...] Henrique Valpolo. Madrid: Pedro de Madrigal, 1596.

Croft, Pauline. "Englishmen and the Spanish Inquisition." English Historical Review 87 (1972): 249-68.

_-_ ed. The Spanish Company. London: London Record Society, 1973.

__—. "Trading with the Enemy, 1585-1604." Historical Journal 32 (1989): 281-302.

De Mornay, Philippe. A Worke concerning the Trewnesse of Christian Religion. London: Robert Robinson for I.B., 1592.

Domingo Malvadi, Arantxa. Bibliofilia humanista en tiempos de Felipe II: La biblioteca de Juan Páez de Castro. Salamanca: Universidad de Salamanca, 2011.

Domínguez, Freddy Cristóbal. “We Must Fight with Paper and Pens': Spanish Elizabethan Polemics 1585-1598”. PhD diss., Princeton University, 2011.

Fallows, David. "English Song Repertories of the Mid-fifteenth Century.” Proceedings of the Royal Musical Association 103 (1976-77): 61-79.

Flavin, Susan, and Evan T. Jones, eds. Bristol's Trade with Ireland and the Continent: The Evidence of the Exchequer Customs Accounts. Dublin: Four Courts Press, 2009.

Foxe, John. Acts and monuments. [London]: [John Day], [1562-63].

- - - Locorum communium tituli \& ordines centum quinquaginta. Basel: Ex officina Ioannis Oporini, 1557.

Gibbons, John. Concertatio Ecclesiae catholicae in Anglia aduersus calvinopapistas et puritanos. Trier: Henricus Bock, 1588.

Gonzalo Sánchez-Molero, José Luis. “Philippus, rex Hispaniae \& Angliae: La biblioteca inglesa de Felipe II." Reales sitios 160 (2004): 14-31.

Gregory, Brad. "The 'True and Zealous Service of God': Robert Persons, Edmund Bunny and the First Booke of the Christian Exercise." Journal of Ecclesiastical History 45 (1994): 238-68. 
Guirau Cabas, José Manuel, and José Luis del Valle Merino. Catálogo de impresos de los siglos XVI-XVIII de la Real Biblioteca del Monasterio de San Lorenzo del Escorial. Madrid: Patrimonio Nacional, 2010-12.

Hall, Joseph. Epistles: The First Volume, Conteining Two Decads. London: Printed by A.H. for Eleazar Edgar \& Samuel Macham, 1608.

Highley, Christopher. Catholics Writing the Nation in Early Modern Britain. Oxford: Oxford University Press, 2008.

Hoftijzer, P. [Paul] G. "British Books Abroad: The Continent." In The Cambridge History of the Book in England: Vol. IV; 1557-1695, edited by John Barnard and D.F. [Donald Francis] McKenzie, 735-43. Cambridge: Cambridge University Press, 2002.

Houliston, Victor. Catholic Resistance in Elizabethan England. Aldershot: Ashgate, 2007.

- - - "Why Robert Persons Would Not Be Pacified: Edmund Bunny's Theft of The Book of Resolution." In The Reckoned Expense: Edmund Campion and the Early Jesuits, edited by Thomas M. McCoog, 209-32. Woodbridge: Boydell, 1996; 2nd ed., Rome: Institutum Historicum Societatis Iesu, 2007.

Hughes, Paul, ed. Tudor Royal Proclamations: Vol. III. New Haven: Yale University Press, 1969.

Jessop, William. "Privateering in Elizabethan Bristol: A Case Study on John Hopkins.” MA diss., University of Bristol, 2004.

Kamen, Henry. The Escorial: Art and Power in the Renaissance. New Haven: Yale University Press, 2010.

Lezcano Tosca, Hugo. "Lecturas espirituales prohibidas en la Real Biblioteca de El Escorial (siglo XVI).” Libros de la Corte.es 6 (2013): 76-120.

Loomie, Albert J. "Religion and Elizabethan Commerce with Spain." Catholic Historical Review 50 (1964): 27-51.

———. "Thomas James: The English Consul of Andalucia 1556-c.1613." Recusant History 11 (1972): 165-78.

Martínez de Bujanda, Jesús. El índice de libros prohibidos y expurgados por la Inquisición española (1551-1819). Madrid: Biblioteca de Autores Cristianos, 2016.

- - - Thesaurus de la littérature interdite au XVIe siècle: Auteurs, ouvrages, éditions avec addenda et corrigenda. Paris: Librairie Droz, 1996. 
Martínez de Bujanda, Jesús, and Marcella Richter. Index des livres interdits: Index librorum prohibitorum 1600-1966. Montréal, Geneva, and Sherbrooke: Médiaspaul, Droz, and Université de Sherbrooke, 2002.

Martínez Ripoll, Antonio. "La controversia sobre la reconstrucción del Templo de Salomón entre Arias Montano y los jesuitas del Prado y Villalpando." In Fe y sabiduría: La biblioteca. IV Centenario del Monasterio de El Escorial, edited by Francisco Solano, 53-74. Madrid: Patrimonio Nacional, 1986.

McCoog, Thomas M., S.J. "And Touching Our Society": Fashioning Jesuit Identity in Elizabethan England. Toronto: Pontifical Institute of Mediaeval Studies, 2013.

-—- English and Welsh Jesuits 1555-1650: Part II, G-Z. Catholic Record Society 75. Southampton: Catholic Record Society, 1995.

Major, John. Historia maioris Britanniae, tam Angliae quam Scotiae. [Paris]: Ex officina Ascensiana, 1521.

Manso Porto, Carmen. Don Diego Sarmiento de Acuña, conde de Gondomar (1567-1626): Erudito, mecenas y bibliófilo. Santiago de Compostela: Xunta de Galicia, 1996.

Minshew, John. A Dictionarie in Spanish and English [...] Enlarged and Amplified. London: Edm. Bollifant, 1599.

Moffett, Thomas. Nosomantica Hippocratea, siue Hippocratis prognostica. Frankfurt am Main: Apud heredes Andreae Wecheli, Claudium Marnium \& Ioannem Aubrium, 1588.

Monastery of San Lorenzo de El Escorial.

Murphy, Martin. St Gregory's College, Seville, 1592-1767. Catholic Record Society 73. London: Catholic Record Society, 1992.

Nieto Jiménez, Lidio, and Manuel Alvar Ezquerra, eds. Nuevo tesoro lexicográfico del español (s. XIV-1726). Madrid: Arco-Libros, 2007.

O'Connor, Thomas. Irish Voices from the Spanish Inquisition: Migrants, Converts and Brokers in Early Modern Iberia. Basingstoke: Palgrave Macmillan, 2016.

Páez de Castro, Juan. Memoria a Felipe II sobre la utilidad de juntar una buena biblioteca: Descubierta en la Real Librería de San Lorenzo por Blas Antonio Nasarre. Valladolid: Junta de Castilla y León, 2003.

Pardo-Tomás, José. “Censura inquisitorial y lectura de libros científicos: Una propuesta de replanteamiento." Tiempos modernos 4, no. 9 (2003): 1-18. 
Patterson, Mary Hampson. Domesticating the Reformation: Protestant Best Sellers, Private Devotion, and the Revolution of English Piety. Madison: Fairleigh Dickinson University Press, 2007.

Perkins, William. A Golden Chaine: Or, the Description of Theologie. London: Iohn Legatte, 1612.

Persons, Robert. Elizabethae Angliae Reginae haeresim caluinianam propugnantis, saeuissimum in catholicos sui regni edictum [...] cum responsione. Augsburg: Apud Ioannem Fabrum, 1592.

_-_ Relacion que embiaron las religiosas del Monesterio de Sion de Inglaterra [...] al padre Roberto Personio. Translated by Charles Tankard. Madrid: biuda de P. Madrigal, 1594.

Petti, Anthony G., ed. The Letters and Despatches of Richard Verstegan, c.1550-1640. Catholic Record Society 52. London: Catholic Record Society, 1959.

Pinto Crespo, Virgilio. Inquisición y control ideológico en la España del siglo XVI. Madrid: Taurus, 1983.

Portuondo, María M. “The Study of Nature, Philosophy, and the Royal Library of San Lorenzo of the Escorial." Renaissance Quarterly 63 (2010): 1106-50.

Powell, John W.D. Bristol Privateers and Ships of War. Bristol and London: J.W. Arrowsmith, 1930.

Redworth, Glyn. The Prince and the Infanta: The Cultural Politics of the Spanish Match. New Haven: Yale University Press, 2003.

Rope, H.E.G. [Henry Edward George]. "John Davies of Hereford, Catholic and Rhymer." Anglo-Welsh Review 28 (1961): 20-36.

Ruiz, Elisa. “La pasión anticuaria al servicio de Felipe II.” In El libro en Palacio y otros estudios bibliográficos, edited by Pedro M. Cátedra García and M. Luisa LópezVidriero Abello, 243-64. Salamanca: Universidad de Salamanca, 1996.

Sáez-Hidalgo, Ana. “St. Alban's English College, Valladolid: Enclave or Doorway to the Reception of English Books in Spain?" South Atlantic Review 79 (2014): 105-23.

Samson, Alexander, ed. The Spanish Match: Prince Charles's Journey to Madrid, 1623. Farnham: Ashgate, 2006.

Sandler, Lucy Freeman. "An Early Fourteenth-Century English Psalter in the Escorial." Journal of the Warburg and Courtauld Institutes 42 (1979): 65-80. 
Sandoval, Bernardo de. Index librorum prohibitorum et expurgatorum. Madrid: Apud Ludouicum Sanchez, 1612.

San Segundo Manuel, Rosa. Sistemas de organización del conocimiento: la organización del conocimiento en las bibliotecas españolas. Madrid: Universidad Carlos III-Boletín Oficial del Estado, 1996.

Sigüenza, José de. La fundación del Monasterio de El Escorial. Valencia: CMC, 2010.

Stonyhurst College, Lancashire.

St. Alban's College, Valladolid.

Thomas, Werner. La represión del protestantismo en España: 1517-1648. Leuven: Leuven University Press, 2001.

Wadsworth, James [Sr.]. The Copies of Certaine Letters Vvhich Haue Passed betweene Spaine and England in Matter of Religion. London: Printed by William Stansby for William Barret and Robert Milbourne, 1624.

Walsham, Alexandra. "The Spider and the Bee: The Perils of Printing for Refutation in Early Tudor England." In Tudor Books and Readers: Materiality and the Construction of Meaning, edited by John N. King, 163-90. Cambridge: Cambridge University Press, 2010.

Williams, Michael E. St Alban's College, Valladolid: Four Centuries of English Catholic Presence in Spain. London: Hurst, 1986.

Worthington, David. Scots in the Habsburg Service, 1618-1648. Leiden: Brill, 2004. 